\title{
Influence of the Diffusion Effect Caused by Welding Heat Input Lead to the Changes of Mechanical Properties Which Entering into the FEM Model of Cladding Tube Bending
}

\author{
Jakub Horváth, Jiří Janovec, Michal Junek \\ Department of Material Engineering, Mechanical Faculty, Czech Technical University, Prague, Czech Republic \\ Emial address: \\ Jakub.Horvath@fs.cvut.cz (J. Horváth), Jiri.Janovec@fs.cvut.cz (J. Janovec), Michal.Junek@fs.cvut.cz (M. Junek)
}

\section{To cite this article:}

Jakub Horváth, Jiří Janovec, Michal Junek. Influence of the Diffusion Effect Caused by Welding Heat Input Lead to the Changes of Mechanical Properties Which Entering into the FEM Model of Cladding Tube Bending. International Journal of Materials Science and Applications. Vol. 4, No. 6, 2015, pp. 403-408. doi: 10.11648/j.ijmsa.20150406.16

\begin{abstract}
This paper deal with redistribution of chemical elements around cladding surface of composite tube. Motivation is that change of chemical composition cause change in microstructure and mainly changes in mechanical properties. Local changes of mechanical properties can cause inaccuracy or wrong results obtained from FEM modeling of bending process of cladding tube. In short paper present redistribution of chemical elements caused by heat input during production of tube. Redistribution caused by heat input from weld attachment of connector which is used during production of membrane waterwall is discussed. Microstructure evaluation of base material and cladding layer is compared with measurement of hardness. Measurement of microhardness in specific areas of cladding tube was done. Microhardness is compared with measurement of chemical composition via EDX in scanning electron microscope.
\end{abstract}

Keywords: Cladding Tube, Welded Joint, SEM, Light Microscopy, Diffusion

\section{Introduction}

After reconstruction of high parametric coal power plants in the Czech Republic in the last 10 years there has been high-exfoliation of superheaters. The steam oxidation resistance increases with an increase in the concentration of chromium and the alloying $\mathrm{Nb}$ optionally $\mathrm{Ti}$ in austenitic steels. Furthermore, increasing the stability of austenitic phase of growth the concentration of nickel but also nitrogen. Alloying molybdenum has no direct influence on the formation of the protective chromium oxide or spinels.

Study steam side magnetite formation on austenitic steels at $600-700^{\circ} \mathrm{C}[1],[2]$, has led to the fact that the original steel $347 \mathrm{H}$ and $304 \mathrm{H}$ were developed in the 80 s steel HFG (Fine grained) and HSB or HSP ( shot blasted or shot peening). Pipes of these fine-grained or blasted austenitic steels exhibit comparable resistance to steam oxidation behavior of high-alloyed austenitic steels HR3C and NF709.

Cheaper production component boilers brought cladding tubes. Technology of production of clad tubes was mastered by many other manufacturers (Figure 1, [6]) and a gradual decline in prices of clad tubes makes them an alternative to the use of homogeneous tubes of high-quality metal, or to use overlay. Using clad tubes is subject by mastering the technological operations necessary for producing the normal technical equipment. One of technologically operation is bending of tubes. There is possibility to modeling of bend via FEM modeling. Another technological operations is welding of tubes into the shape of water walls. Welding can caused redistribution of chemical composition and through that change mechanical properties of clad tube. The paper describes some steps of investigation of influence of welding to the cladding tubes.

\section{Test Experimental Materials}

Diameters of the cladding tube and layers thickness are shown in Table 1[3]. Chemical compositions of used materials are demonstrated in Table 2 and Table $3[4,5]$.

Table 1. Tube specification.

\begin{tabular}{ll}
\hline Sandvik 3R12/4L7 OD 76,2 x 6,58 \\
\hline Outer diameter & $72,9 \mathrm{~mm}$ \\
Total wall thickness & $6,58 \mathrm{~mm}$ \\
Sandvik 3R12 thickness & $1,65 \mathrm{~mm}$ \\
\hline
\end{tabular}


Table 2. Sandvik 3R12.

\begin{tabular}{lllllll}
\hline $\mathbf{C}$ & $\mathbf{S i}$ & $\mathbf{M n}$ & $\mathbf{P}$ & $\mathbf{S}$ & $\mathbf{C r}$ & $\mathbf{N i}$ \\
\hline$\leq 0.03$ & 0.5 & 1.3 & $\leq 0.03$ & $\leq 0.01$ & 18.5 & 10 \\
\hline
\end{tabular}

Table 3. Sandvik $4 L 7$.

\begin{tabular}{lllll}
\hline $\mathbf{C}$ & Si & Mn & P & S \\
\hline$\leq 0.20$ & 0.3 & 0.7 & $\leq 0.025$ & $\leq 0.020$ \\
\hline
\end{tabular}

\section{Production route of composite tubes}

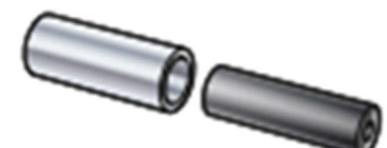

Inner and outer component

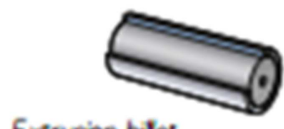

Extrasion bilet

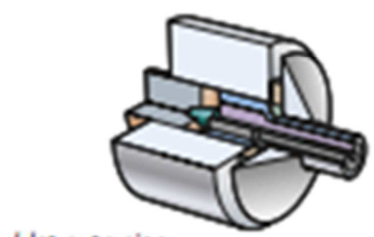

Hox extrusion

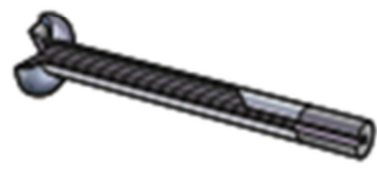

Extruded composite tube or composite hollow

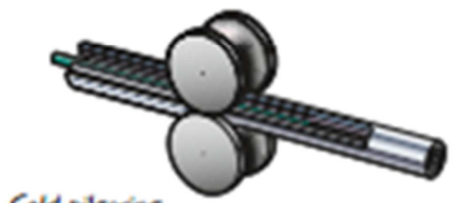

Cold pigering

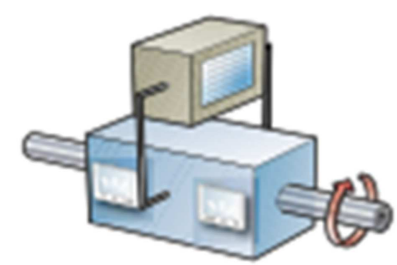

Non destructive testing

Figure 1. Production of cladding tubes.

\section{Results of Material Testing}

\subsection{Influence of Bending}

Experimental bend was realized on bending machine with inductor heating of tube. Inductor heat small ring of material which is preferably used for location of deformation. Process of bending are shown in Figure 2.

First step was modeling of bend made from clad tube. The aim of modeling was calculation of deformations across the tube (Figure 3, [8]) and shear stresses at the cladding surface. FEM model was firstly used for modeling bend made from cladding tube Sanicro38/4L7. Results of shear stresses from modeling of tube segments for tension, pressed and neutral part of tube are plotted in Figure 4.

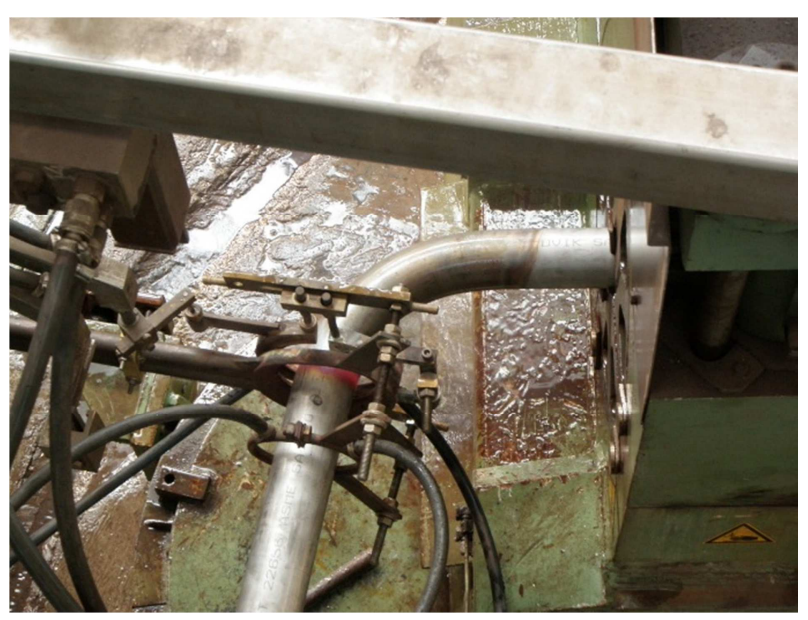

Figure 2. Upper view during bending.

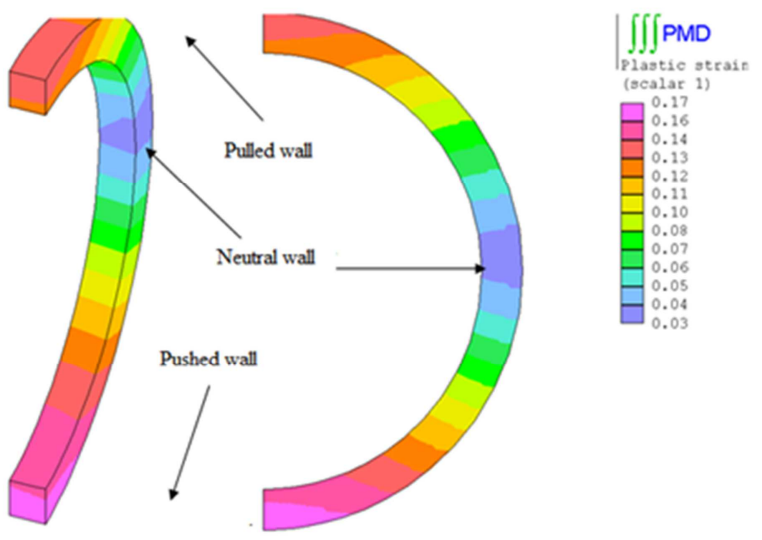

Figure 3. Scheme of deformations across the tube.

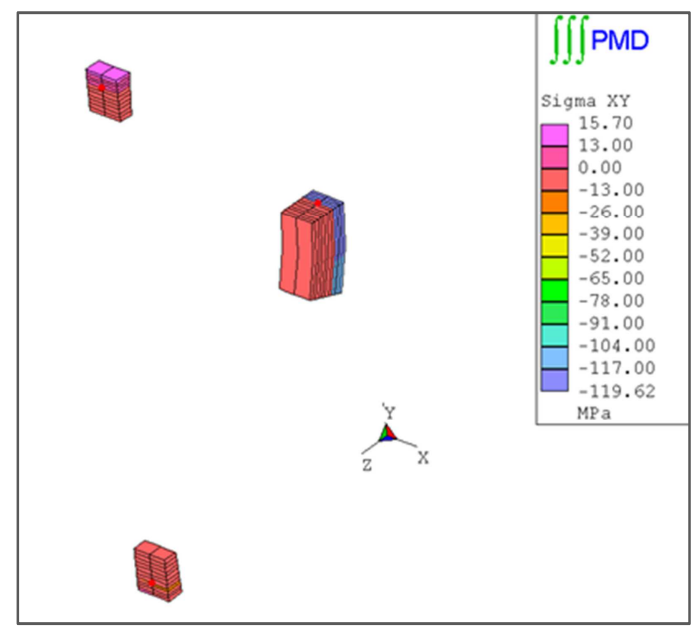

Figure 4. Shear stresses in the XY plane. 
Results from FEM modeling was compared with measurement of critical shear stresses which caused delamination of cladding layers. Comparison of calculated shear stresses and critical shear stress confirm correct bending parameters and gave possibility to make real bend of tubes without problems with delamination of layers $[7,8]$.

Microscopy confirmed homogenous of clad surface without delamination. Microstructure near cladding surface is shown in Figure 5. There is a carbon depleted zone with thickness up to $85 \mu \mathrm{m}$. Diffusion of carbon is caused by heat input during producing of tube and by different in carbon content in Sanicro 38 and 4L7 [9]. Diffusion into Sanicro 38 is retarded by high content of nickel. Difference in content of carbon across cladding surface is marked with red color in Figure 6.

Table 4. Chemical composition of Sanicro 38

\begin{tabular}{ll}
\hline Sanicro 38 & \\
\hline $\mathrm{C}$ & $\leq 0,03$ \\
$\mathrm{Si}$ & $\leq 0,5$ \\
$\mathrm{Mn}$ & 0,8 \\
$\mathrm{Cr}$ & 20 \\
$\mathrm{Ni}$ & 38,5 \\
$\mathrm{Mo}$ & 2,6 \\
$\mathrm{Cu}$ & 1,7 \\
$\mathrm{Ti}$ & 0,8 \\
\hline
\end{tabular}

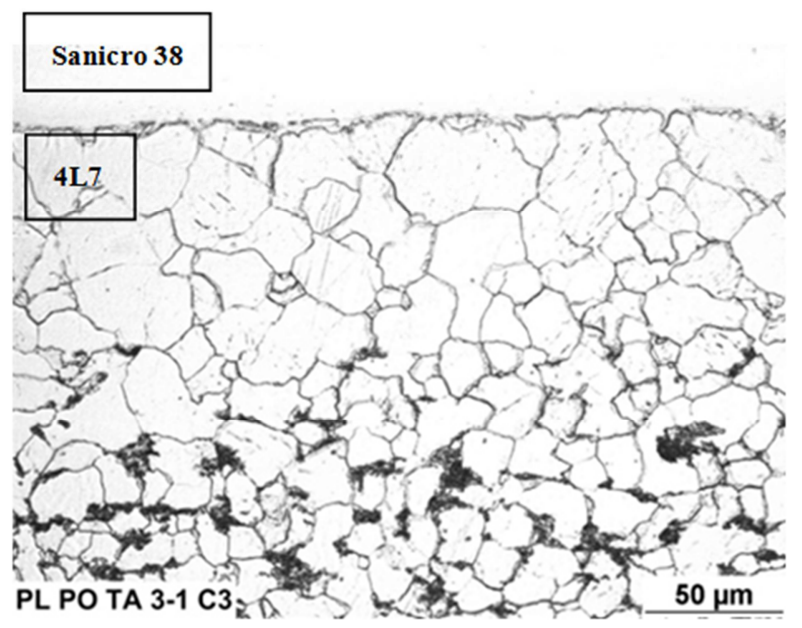

Figure 5. Structure around the cladding surface.

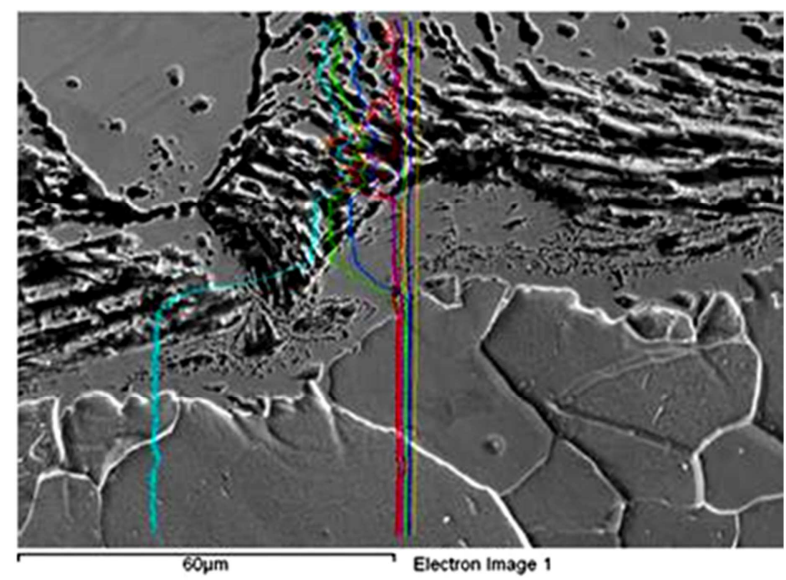

Figure 6. Line analyses across cladding surface.
Measurement of chemical composition and microhardness (Figure 7) suggests differences in mechanical properties around cladding surface. Those differences can cause deviation between FEM model and real bend.

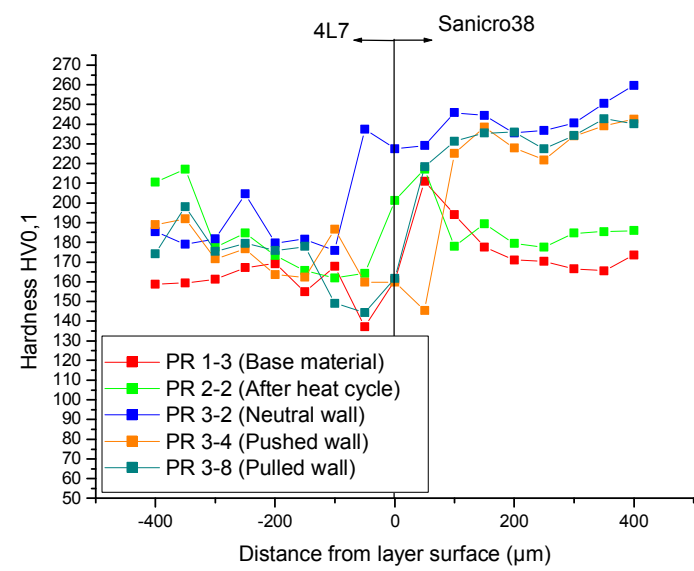

Figure 7. The measurement of microhardness.

\subsection{Influence of Welding}

Above mentioned redistribution of chemical composition caused by heat input during producing of tubes isn't significant in case of combination Sanicro38/4L7. Sanicro contain $38 \%$ of nickel which acts as a diffusion barrier. Combination of $3 \mathrm{R} 12$ and $4 \mathrm{~L} 7$ can exhibit different. Steel 3R12 contain $10 \%$ of nickel. Another difference can be caused by welding joints of tubes together into tube walls. Scheme of cutting of tube is shown in Figure 8. Macro photos of cuts from the tube are in Figure 9.

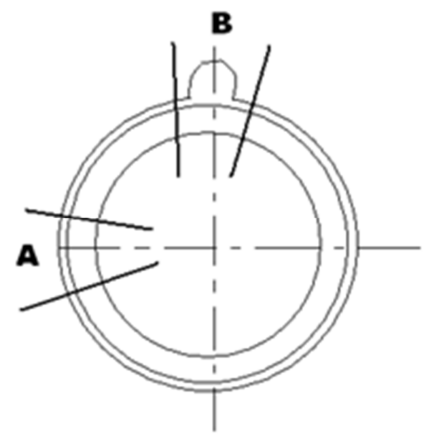

Figure 8. Scheme of cut of the tube.
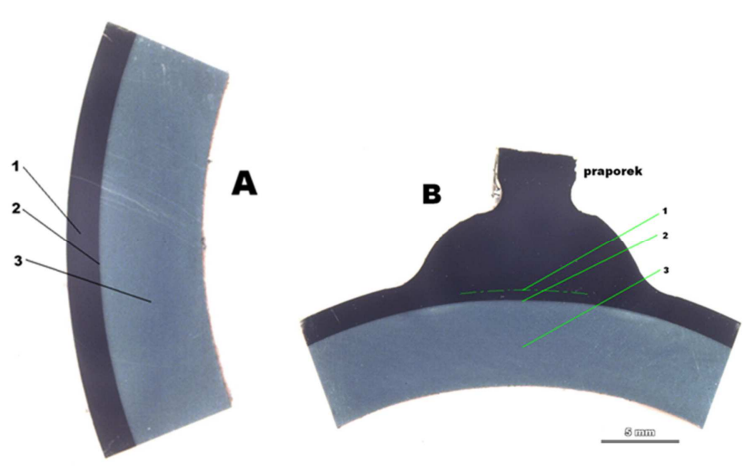

Figure 9. Cuts from the tube. 


\subsubsection{Microstructures}

Recrystallized microstructure of steel 4L7 with fine lamellar perlite and grain size 9 [10] is shown in Figure 10. In Figure 11 austenitic structure of steel 3R12 with grain size 7 [10], twins and disperse carbides is presented.

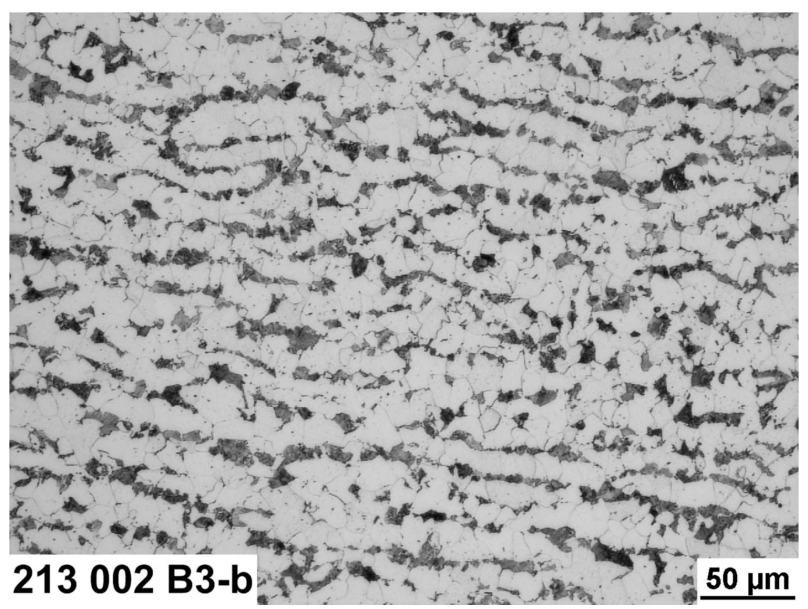

Figure 10. Microstructure of steel $4 L 7$ (320x).

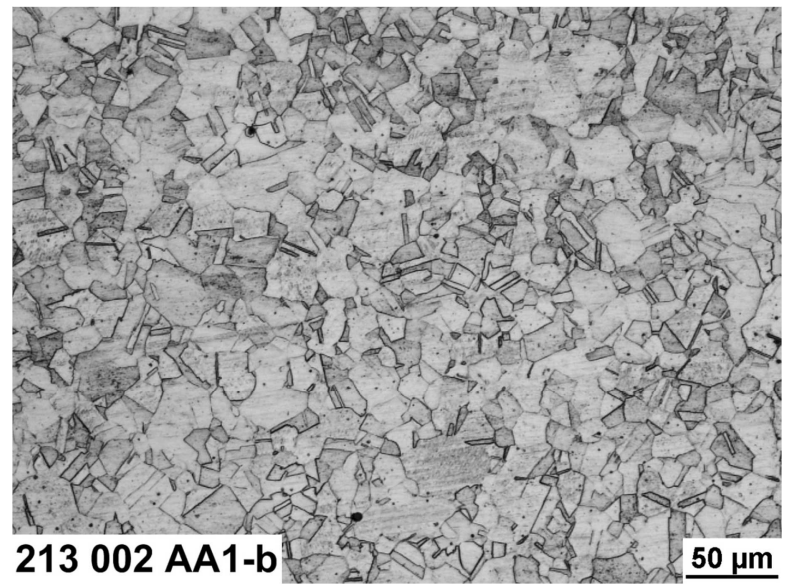

Figure 11. Microstructure of steel $3 R 12(320 x)$.

Carbon depleted zone in steel 4L7 with thickness about $110 \mu \mathrm{m}$ and rougher grain in comparison with base material (Grain size 7 [10]) is presented in Figure 12.

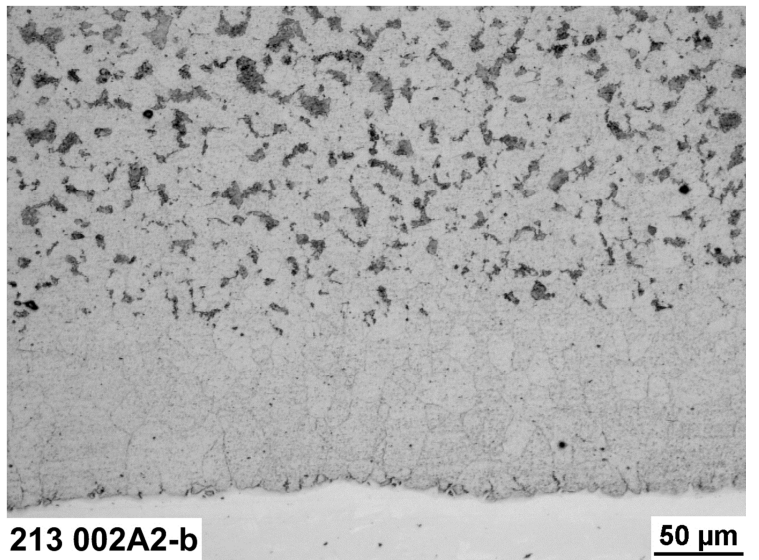

Figure 12. Microstructure of cladding surface side of steel 4 L7 (320x).
Austenitic structure near cladding surface containing carbide precipitation and $5 \mu \mathrm{m}$ thickness zone with high concentration of slipping lines is shown in Figure 13.

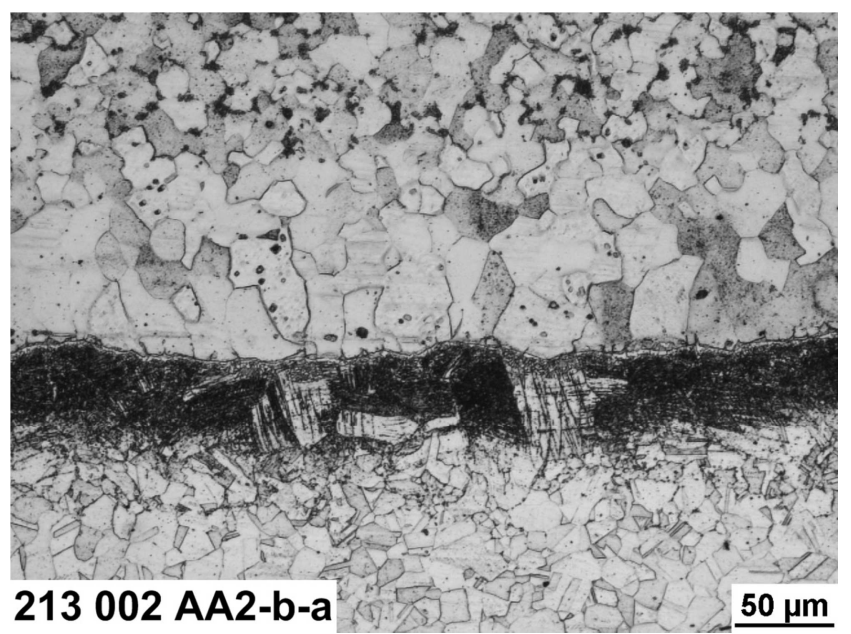

Figure 13. Microstructure of cladding surface side of steel 3R12 (320x).

\subsubsection{Hardness Measurement}

Position of hardness measurement one can see in Figure 14 Comparison of hardness measurement results is listed in Table 5. There is possible to see difference among base tube and tube under connection weld. Value of measured hardness was higher under weld for both materials. Difference is about 20 HV 10.

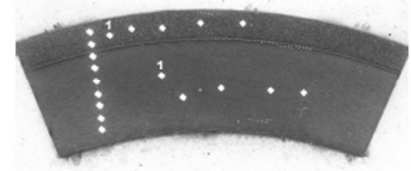

213002-A $213002 \mathrm{~A}$

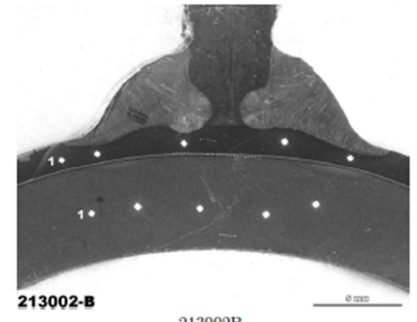

213002B
Figure 14. Position of hardness measurement.

Table 5. Measurement of hardness.

\begin{tabular}{lll}
\hline Measured crossection & Structure & Average hardness \\
\hline \multirow{2}{*}{ Crossection A } & austenite & $172 \pm 2 \mathrm{HV} 10$ \\
& ferrite & $151 \pm 4 \mathrm{HV} 10$ \\
Crossection B & austenite & $192 \pm 5 \mathrm{HV} 10$ \\
& ferrite & $167 \pm 4 \mathrm{HV} 10$ \\
\hline
\end{tabular}

\subsubsection{Microhardness Measurement}

Microhardness across cladding surface is shown in Figure 15. Value 0 at $X$ axis represent cladding surface. Positive positions represent measured value in austenite (3R12) and negative in ferrite (4L7).

Carbon depleted zone in steel 4L7 exhibit lower hardness, but carbon enrich zone in austenitic steel 3R12 exhibit markedly higher microhardness in comparison with base austenite material. 


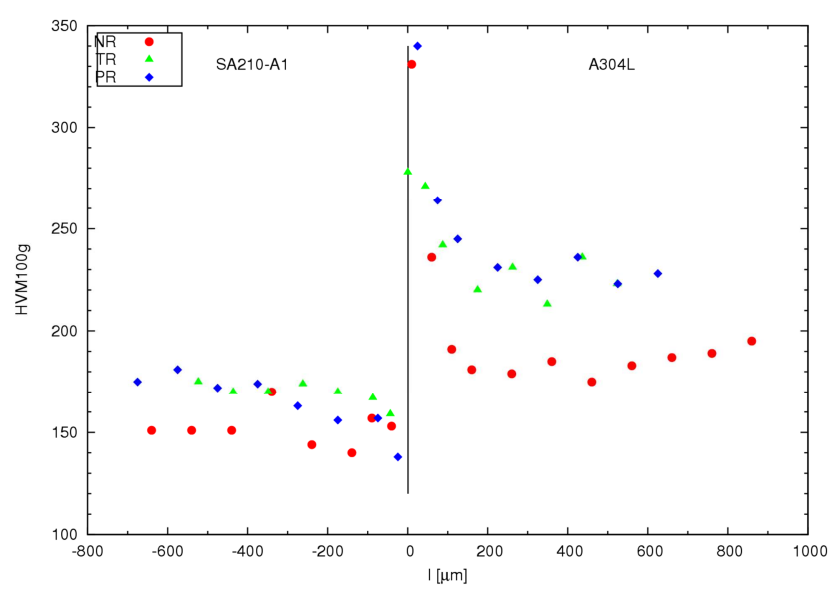

Figure 15. Microhardness around cladding surface.

In order to better describe of hardness pursuant on chemical composition several areas was selected and named oblast I - oblast VII (Figure16). In these areas was measured microhardness and chemical composition. In each area was done five measurement of microhardness with increments $0,2 \mathrm{~mm}$. Results of microhardness measurement are listed in Table 6.

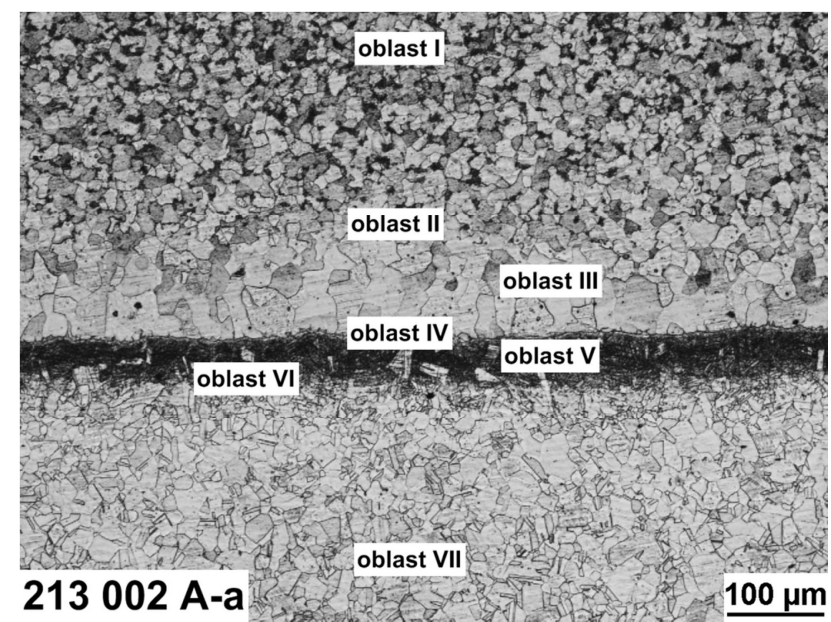

Figure 16. Zones for measurement of Microhardness around cladding surface.

Table 6. Results of Microhardness measurement around cladding surface.

\begin{tabular}{lll}
\hline Crossection & Area & Average hardness \\
\hline & I & $179 \pm 3 \mathrm{HV} 0,1$ \\
II & $146 \pm 9 \mathrm{HV} 0,1$ \\
Crossection A & III & $142 \pm 7 \mathrm{HV} 0,1$ \\
& IV & $216 \pm 22 \mathrm{HV} 0,1$ \\
& V & $369 \pm 41 \mathrm{HV} 0,1$ \\
VI & $269 \pm 16 \mathrm{HV} 0,1$ \\
& VII & $229 \pm 12 \mathrm{HV} 0,1$ \\
& I & $171 \pm 13 \mathrm{HV} 0,1$ \\
II & $154 \pm 4 \mathrm{HV} 0,1$ \\
III & $154 \pm 3 \mathrm{HV} 0,1$ \\
IV & $223 \pm 13 \mathrm{HV} 0,1$ \\
& V & $405 \pm 36 \mathrm{HV} 0,1$ \\
& VI & $232 \pm 6 \mathrm{HV} 0,1$ \\
VII & $227 \pm 7 \mathrm{HV} 0,1$ \\
\hline
\end{tabular}

\subsubsection{Chemical Composition Measurement}

Measurement of chemical composition was done by EDX at the scanning electron microscope JEOL.

Positions of measured areas for crossection A are shown in Figure 17. Equivalent full spectra are plotted in Figure 19.

Table 7 summarized results of measurement of chemical composition of crossection A.

Positions of measured areas for crossection B are shown in Figure 18. Equivalent full spectra are plotted in Figure 20.

Table 8 summarized results of measurement of chemical composition of crossection B.

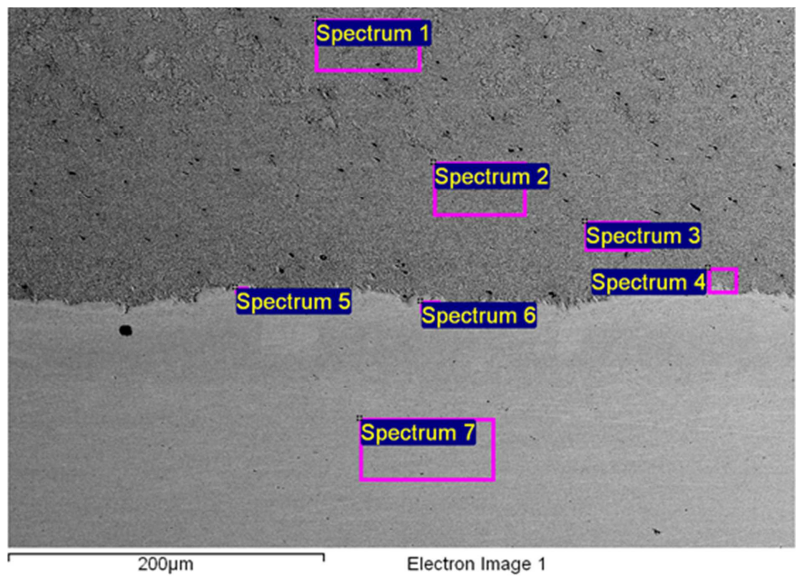

Figure 17. Position of chemical composition measurement areas for crossection $A$.

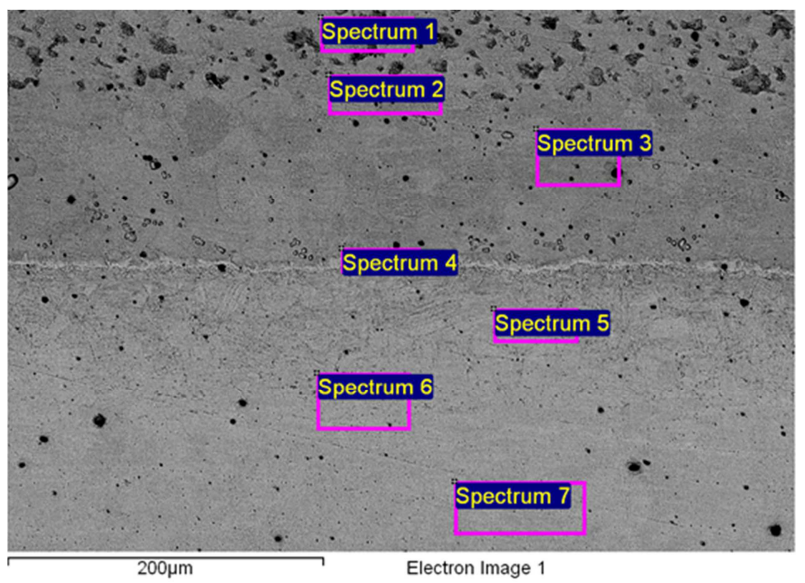

Figure 18. Position of chemical composition measurement areas for crossection $B$.

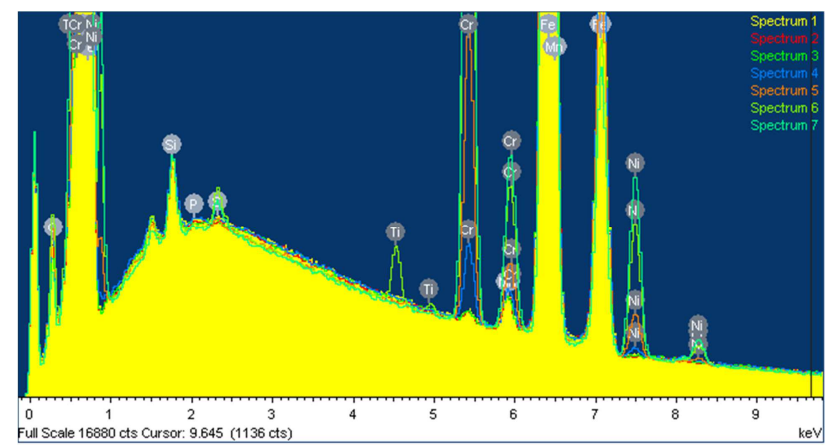

Figure 19. Comparison of full spectra for crossection A. 


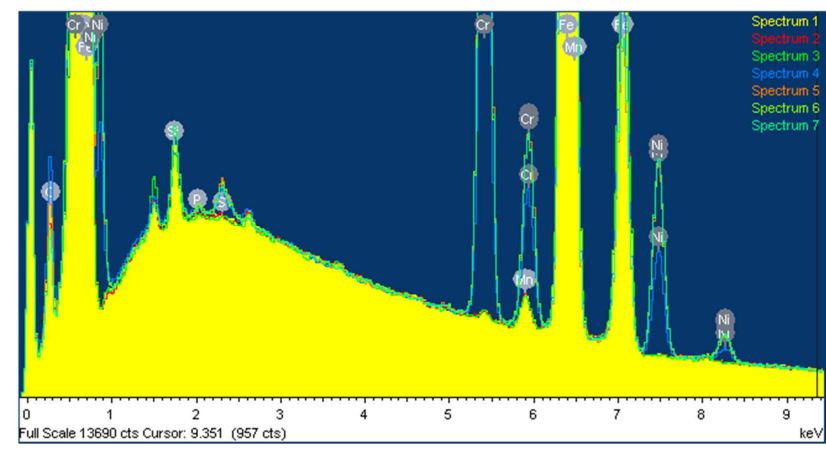

Figure 20. Comparison of full spectra for crossection $B$.

Table 7. Summarize table of chemical composition for crossection A.

\begin{tabular}{lllllll}
\hline Spectrum & C & Si & Cr & Mn & Fe & Ni \\
\hline Spectrum 1 & 3.22 & 0.41 & & 0.76 & 95.56 & \\
Spectrum 2 & 3.12 & 0.44 & & 0.79 & 95.60 & \\
Spectrum 3 & 2.70 & 0.42 & & 0.81 & 96.03 & \\
Spectrum 4 & 3.19 & 0.42 & 1.13 & 0.78 & 93.87 & 0.55 \\
Spectrum 5 & 3.78 & 0.40 & 4.80 & 0.91 & 87.55 & 2.48 \\
Spectrum 6 & 4.35 & 0.46 & 13.66 & 1.44 & 71.94 & 7.19 \\
Spectrum 7 & 2.48 & 0.50 & 18.64 & 1.42 & 66.86 & 9.91 \\
\hline
\end{tabular}

Table 8. Summarize table of chemical composition for crossection B.

\begin{tabular}{lllllll}
\hline Spectrum & C & Si & Cr & Mn & Fe & Ni \\
\hline Spectrum 1 & 4.24 & 0.44 & & 0.75 & 94.54 & \\
Spectrum 2 & 3.65 & 0.41 & & 0.77 & 95.10 & \\
Spectrum 3 & 3.47 & 0.44 & & 0.75 & 95.29 & \\
Spectrum 4 & 5.34 & 0.44 & 12.47 & 1.17 & 75.11 & 5.30 \\
Spectrum 5 & 3.98 & 0.47 & 19.52 & 1.36 & 64.97 & 9.47 \\
Spectrum 6 & 3.05 & 0.50 & 18.73 & 1.42 & 66.40 & 9.70 \\
Spectrum 7 & 3.01 & 0.51 & 18.44 & 1.44 & 66.58 & 9.84 \\
\hline
\end{tabular}

\section{Conclusions}

- It was confirmed that it is possible to model bending process of cladding tube

- In case of tube with high nickel content cladding layer is diffusion of chemical elements negligible

- Cladding tube with layer containing lower content of alloying elements (especially nickel which act like diffusion barrier) exhibit more changes in microstructure and in mechanical properties

- There is higher thickness of carbon depleted zone in steel type 4L7. In this zone is documented drop of microhardness

- Influence of welding is unfavorable. Weld mean higher heat input which accelerated diffusion of chemical components

- These changes of chemical composition lead to decrease of hardness in dough layer of cladding tube

- Weld caused higher differences in microhardness around the cladding surface. There is difference in microhardness around $250 \mathrm{HV} 0,1$. Increase in microhardness is caused by carbon diffusion followed by precipitation of carbides around cladding surface

- Difference in microhardness suggests high differences in all mechanical properties of tube layers

- It will be necessary to include this differences into FEM bending model of cladding tubes

\section{Acknowledgements}

This work was supported by TA ČR program Alfa, project No TA03010150 and by the Ministry of Education, Youth and Sport of the Czech Republic program NPU1, project No LO1207.

\section{References}

[1] Otsuka, N.-Fujikava, H.: Corrosion-vol. 47, No.4, NACE 1991.

[2] Tossey, Brett, Khan, Hassan: Steam Oxidation Resistance of Shot Peened Austenitic Stainless Steel Superheater Tubes, NACE CORROSION 2011 (Paper 19493).

[3] Composite tube for boilers. Sandvik Materials Technology [online]. Sandviken, Sweden [cit. 2015-11-06]. Available from: $\mathrm{http}: / /$ smt.sandvik.com/en/products/tube-pipe-fittings-and-flan ges/tubular-products/composite-tubes/

[4] Sandvik Bioline 3R12: Tube and pipe, seamless. Sandvik Materials Technology [online]. Sandviken, Sweden, 16.9.2015 [cit. 2015-11-06]. Available from: http://smt.sandvik.com/en/materials-center/material-datasheets /tube-and-pipe-seamless/sandvik-bioline-3r12/

[5] Sandvik 4L7: Tube and pipe, seamless. Sandvik Materials Technology [online]. Sandviken, Sweden, 8.6.2015 [cit. 2015-11-06]. Available from: http://smt.sandvik.com/en/materials-center/material-datasheets /tube-and-pipe-seamless/sandvik-417

[6] L. Horváth, M. Svobodová, T. Chmela, I. Andršová and J. Horváth. "Odborná zpráva o postupu prací a dosažených výsledcích za rok 2013, Číslo projektu: TA03010150: Výzkum vlastností a chování tlustostěnných plátovaných trub-kových ohybů $\mathrm{v}$ podmínkách ekonomicky významných aplikací, včetně zvládnutí jejich výroby ověřené certifikovaným orgánem s evropskou působností." Praha, 2014.

[7] J. Horváth, J. Janovec, "Modeling and verification of the cladding tube bend", IJESRT, vol.4, October, 15, 2015.

[8] M. Smejkal "Stanovení odhadu plastické defrmace plátované trubky z materiálů Sanicro 38 a $4 \mathrm{~L} 7$ při ohybu s indukčním ohřevem": Praha, 2014.

[9] R. E. Smallman, A. H. W. NGAN, Modern Physical Metallurgy, 8th Ed., Butterworth-Heinemann, 2013.

[10] Steels - Micrographic determination of the apparent grain size (ISO 643:2013). Praha, 2013. 